本的特性，低扣よび高爆発限界ならびに発火に要する エネルギを詳しく瓦をつけて説明し，最初の発火㴗 するエネルギ必少めて小さく 100 ワット電球 1 秒間 の消費エネルギの100万分の1くらいとのべている.

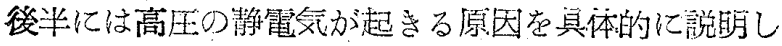

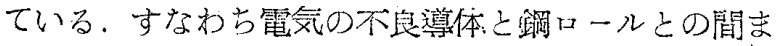
た不良筫体流体と管との間で，エレクトロンの移動に

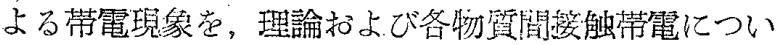

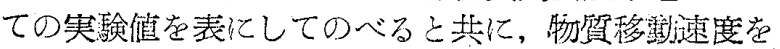

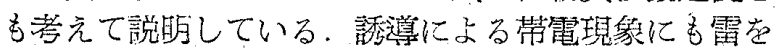
例にしてのべ，徒来原因不明の㤕火もこの種の静䉓気

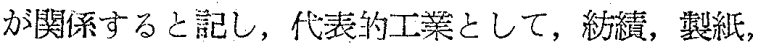
ゴム，プラステック，精油，看機物扣よび金属箎散布， 飛行機等をあげ，斿の打のにつき注意すべき点を特記 し，災篦防止装置を説明し全文にわたり，ての種分野 の文欨を紹介している。

$621-758.34: 621.45$

\section{[277]ターボジェツト発動縄運転場の防吾設誄}

[Howard C. Hardy, The Journal of the Acoustical Society of America Vol. 24, No. 2, 1952-3, p. 185 〜190, 図 10, 表 1] ターボジェット発動機運抎場 壮最終的にどのくらいまで騒琵を下げなくてはなら奴 汃を論じ，10 台発動機をまわすとして $3000 \mathrm{ft}$ 離れ た所で $150 \sim 300 \mathrm{cps}$ 打よび $300 \sim 600 \mathrm{cps}$ の間で 50 ないし $55 \mathrm{db}$ 下げることが必要であるとして，減少

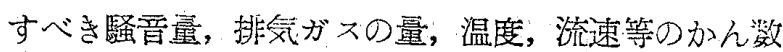

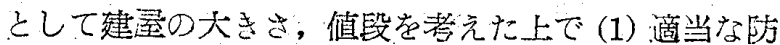
至材による方法，(2) $180^{\circ}$ 亿曲る防害材をつめた通路

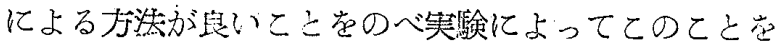
示している。 [今茾萧一郎]

$621-758.34: 621.45$

[278]ターボジェット発動機運転場の音響学的設

棓 [R. O. Fehr, R. J. Wells \& T. L. Bray, The Journal of the Acroustical Society of America, Vol. 24, No. 5, $1952 \sim 9$, p. $480 \sim 489$, 脑 18]

ダーボジェット発舫機の試運転場はその附近の騒音京 減ずることと，運檕場で㗢く人を騒至から護ることが 閒題となる. G. Eの Lockland, Ohio 执よび Lynn. Massachusetts で行った絓験を元にしてのべてある。

50 f離れた弅で Afterburner なしで $130 \mathrm{db}$, Afterburner つきで $140 \mathrm{db}$ くらいである。排気の压力る 上げないで，高温に耐光るような方泎で高い騒豆を娍 ずること堂考えなくてはならない．現在 $1 \mathrm{db}$ 下げる

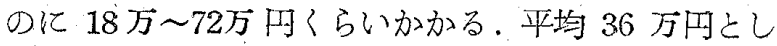
て $50 \mathrm{db}$ 下るとすると 1800 万内となり防至が大き な閐題であることがわかる。まず騒夏の分析を行いイ

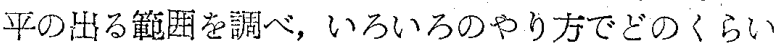
下る內在調べ，更に模型によって試験を行い，笑物乞 比較している，運転場の壁の厚さ，運転壆のやり方，

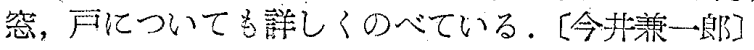

\title{
25. 工業教育
}

\section{$373.63(470)$}

[279] ソ運の工業教育 [Mech. Engg., 1953-5, Vol. 75, No. 5, p. 397〜398] ソ連には工箘關係の 大学が 890 あり，在籍学生数は 140 万人である。絵合

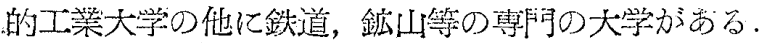

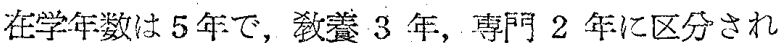

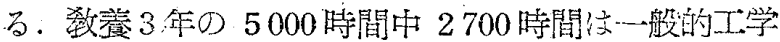
化費され，専间 2 年の 2300 時間中 800 時間住人交関
係鄪される。等門 2 年の間にはアメリカの修士コー スと同様なお沠で㸚授の直接指導による研究が課せら れる。第 4 学年加方第 5 学年に進む前に傚官に引率さ れて笑習にゆき，笑習工場の久陷について指摘した批

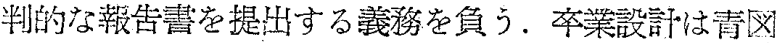

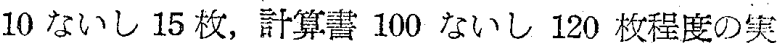
際の製品で，試間委員会に出て試問される，優秀学生: は各種の方洗で㙳遇される。

\subsection{9}

[280] 原子動力開発の現状 [Mech. Engg., 1953 -6, Vol. 75, No. 6, p. 481 485, 図.3, 表 3]

本文位 AEC の S. A. Tucker 印の論文の要約で ある。それぞれ2社より成る4組の研究班が，爷共発 電所用に供しうべき原子動力装置の開発に当ってい る。原子炉で発生する熱を外部に運び出す流体として

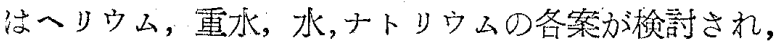

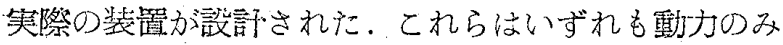
の生座を目的としたものではなく，プルトニりム鈫造 の副産物として電力をとり出す目的であるので, 然料 温度を $540 \sim 590^{\circ} \mathrm{C}$ 亿限定する必要があり，したが

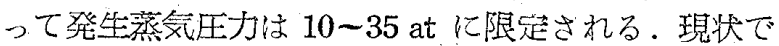
は原子炬周理には広大な空地を設けて放射污損を防が 权ばなら双ととになっているから，都市間辺に原子力 発電所を㴛けること结考光られないが，土地代を别に して考えると，20万 $\mathrm{kW}$ 程度の発電所としてナトり
26. 雜

ウム冷却方式で約 120 ドル $/ \mathrm{kW}$ となり，音道の火小 発䨘所の 169 ドル/kW よりも安い。ただし重水走使

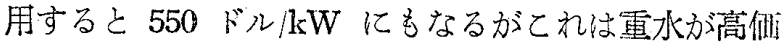
なためである、ウラニウム然料は市販されていないか ら然料費ば眀確にはわ方ないが，石炭よりは安值二 思われるからナトリウム冷却方式で発電すれば経济的 に寻合う可能性动大である。然料は現状では固体とし て使われているが，然粼も液体にした原子炬が最も将 来性ありとみられている。

な打別項（同誌 486 ページ）の記事によると，潜水 艦ノ一チラス昂用の水冷式原子炉の第一次試運転方非 功した由であり，更に别項（同誌 487 ページ）の記等 によると，ノーヂラス号用原子师に必要な Zirconium (高度に耐爇耐食性で中性子直由に透過させる金属) が $250 \mathrm{~kg}$ のインゴットから出発する摘業生産に大， たということである。
[石谷清幹] 